\title{
Kepatuhan Penggunaan Obat terhadap Profil Lipid dan Lingkar Perut pada Pasien Sindrom Metabolik di Rumah Sakit di Semarang
}

\section{Adherence to Anti-diabetic Medication, Lipid Profiles and Abdominal Circumference in Patients with Metabolic Syndromes in Semarang}

\author{
Farroh Bintang Sabiti ${ }^{1 *}$, Nur Anna Chalimah Sa'dyah ${ }^{2}$, Ayu Pambajeng ${ }^{3}$ \\ ${ }^{1}$ Bagian Farmasi Klinik dan Komunitas Program Studi Farmasi Fakultas Kedokteran Universitas Islam Sultan \\ Agung Jl. Kaligawe Raya No.Km 4, Semarang, Indonesia, 50112 \\ ${ }^{2}$ Bagian Fakultas Kedokteran Universitas Islam Sultan Agung, Jl. Kaligawe Raya No.Km 4, Semarang, \\ Indonesia, 50112. \\ ${ }^{3}$ Mahasiswa Program Studi Farmasi Fakultas Kedokteran Universitas Islam Sultan Agung Jl. Kaligawe Raya \\ No.Km 4, Semarang, Indonesia, 50112 \\ *E-mail: Farrahbintang@,unissula.ac.id
}

Received: 16 November 2021; Accepted: 23 Desember 2021; Published: 31 Desember 2021

\begin{abstract}
Abstrak
Sindrom metabolik adalah kelainan metabolik yang diakibatkan oleh peningkatan obesitas secara kompleks. Sindrom metabolik dapat dikontrol dengan patuh minum obat dan gaya hidup yang sehat. Perilaku pasien terhadap kepatuhannya minum obat dilakukan agar tercapainya tujuan pengobatan itu sendiri. Tujuan penelitian untuk menetapkan pengaruh kepatuhan penggunaan obat terhadap profil lipid dan lingkar perut pada pasien sindrom metabolik (SM) di Rumah Sakit di Semarang. Penelitian ini merupakan jenis penelitian observasional. Pengambilan data dilakukan dengan rancangan cross sectional. Pengambilan data pada penelitian ini dilakukan pada bulan Agustus - Desember 2020. Penelitian ini menggunakan uji chi-square, pada uji chi-square untuk lingkar perut didapatkan hasil 0,254 yang mana dikatakan tidak terdapat pengaruh kepatuhan penggunaan obat dengan nilai lingkar perut dan uji chi-square untuk LDL didapatkan hasil 0,046 dan hasil 0,001 untuk trigliserid yang mana dikatakan terdapat pengaruh kepatuhan penggunaan obat dengan kadar LDL dan kadar trgliserid. Kesimpulan pada penelitian ini bahwa ada pengaruh kepatuhan penggunaan obat pasien terhadap kadar LDL (Low Density Lipoprotein) dan kadar trigliserida, sedangkan tidak adanya pengaruh kepatuhan penggunaan obat pasien terhadap nilai lingkar perut.
\end{abstract}

Kata Kunci: Sindrom Metabolik, Kepatuhan, Lingkar Perut, Low Density Lipoprotein, Trigliserida

\begin{abstract}
Metabolic syndrome is a metabolic disorder caused by a complex increase in obesity. Metabolic syndrome can be controlled by adhering to medication and a healthy lifestyle. Patient's behavior towards adherence to medication is carried out in order to achieve the goal of treatment itself. The research objective was to determine the effect of medication adherence on lipid profiles and abdominal circumference in metabolic syndrome (SM) patients at Hospital in Semarang. This research is an observational research. Data were collected using a cross sectional design. Data collection in this study was conducted in August - December 2020. This study used the chi-square test, the chi-square test for abdominal circumference obtained results of 0.254 which said there was no effect of drug adherence with the abdominal circumference value and the chisquare test. for LDL, the results were 0.046 and the results were 0.001 for triglycerides, which is said to have an effect on drug adherence to LDL levels and trglyceride levels. The conclusion in this study is that there is an effect of patient drug use adherence to LDL (Low Density Lipoprotein) and triglyceride levels, while there is no effect of patient drug use adherence to abdominal circumference values.

Keywords: Metabolic Syndrome, Compliance, Abdominal Circumference, Low Density Lipoprotein, Triglycerides
\end{abstract}

\section{PENDAHULUAN}

Sindrom metabolik adalah kelainan metabolik yang diakibatkan oleh peningkatan obesitas secara komples. Dsilipidemia menjadi salah faktor terjadinya sindrom metabolik (Rini, 2015). Dimana dislipidemia 
sendiri suatu kelainan pada metabolisme lipid karena kadar lipid yang mengalami kenaikan atau penurunan, seperti meningkatnya kadar LDL (Low Density Lipoprotien) dan kadar trigliserid (PERKENI, 2019).

Pada data Global Health Observatory (GHO) dari WHO (World Health Organization) menunjukkan pada tahun 2008 prevalensi dislipidemia pada laki-laki sebesar $37 \%$ dan $40 \%$ pada wanita dan tercatat sebanyak 2,6 juta kematian (PERKENI, 2019). Pada penelitian Framingham Offspring Study responden dengan usia 26-82 tahun prevalensi sindrom metabolik $29,4 \%$ pada pria dan $23,1 \%$ pada wanita, sedangkan berdasarkan data Himpunan Studi Obesitas Indonesia (HISOBI) prevalensi sindrom metabolik sebesar 13,13\% (Rini, 2015).

Berdasarkan data yang didapat dari RISKESDAS 2018, di Indonesia kasus sindrom metabolik prevalensinya mencapai $23 \%$. Kondisi kesehatan terkait dengan sindrom metabolik ini digambarkan pada Riset Kesehatan Dasar (RISKESDAS) 2018 diantaranya: proporsi obesitas meningkat dari $14,8 \%$ (Riskesdas 2013) menjadi 21,8\% pada usia dewasa, prevalensi hipertensi meningkat menjadi $34,1 \%$ dari yang semula $25,8 \%$, serta prevalensi diabetus mellitus meningkat dari $6,9 \%$ menjadi $8,5 \%$. Prevalensi sindrom metabolik yang tinggi perlu diwaspadai, karena akan menjadi penyebab baru terjadinya penyakit kardiovaskuler yang menjadi penyebab kematian utama di Indonesia (Magdalena, et al., 2014).

Perilaku pasien terhadap kepatuhannya minum obat dilakukan agar tercapainya tujuan pengobatan itu sendiri. Dislipidemia merupakan suatu kelainan lipid yang memerlukan kepatuhan tinggi dalam penggunaan obat dan memerlukan pengobatan dalam jangka panjang. Namun tidak sedikit pasien yang tidak patuh dalam pengobatan, hal tersebut disebabkan faktor diantaranya kurangnya pengalaman dalam pengelolaan penyakit, sikap kurang peduli terhadap kesehatan bahkan sikap menutupi penyakit dari orang terdekat atau keluarga (Mufarokhah, et al., 2016).

Dua metode yang dapat digunakan untuk mengukur kepatuhan pasien, yaitu metode langsung dan metode tidak langsung (Hussar, 2006). Pada penelitian ini akan menggunakan metode tidak langsung yaitu kuesioner Adherence to Refill and Medication Scale (ARMS). Kuesioner ARMS mudah digunakan, singkat, dan komprehensif serta telah digunakan dalam berbagai penelitian (Kripalani, et al., 2018). Kuesioner ARMS digunakan untuk mengevaluasi kepatuhan pasien dalam minum obat. ARMS ini memiliki skala kepatuhan pengobatan yang valid dan reliable jika digunakan pada pasien dengan penyakit kronis, seperti hipertensi, dislipidemia, diabetus mellitus. Keuntungan dari kuesioner ARMS ini diantaranya dapat digunakan untuk penelitian yang menggunakan populasi sedikit dan literasi yang sedikit pula (Kripalani, et al., 2009)

Berdasarkan permasalahan yang telah diuraikan tersebut perlu dilakukan penelitian mengenai kepatuhan minum obat terhadap kadar trigliserida dan LDL pasien sindrom metabolik di Rumah Sakit di Semarang.

\section{METODE PENELITIAN \\ Rancangan Penelitian}

Penelitian ini merupakan jenis penelitian observasional. Pengambilan data dilakukan dengan rancangan cross sectional.

\section{Variabel Penelitian}

Variabel bebas : kepatuhan penggunaan obat. Variabel terikat : nilai lingkar perut, kadar LDL, kadar trigliserida

\section{Subjek Penelitian}

Kriteria subjek penelitian :

1. Pasien usia $26-70$ tahun

2. Pasien dislipidemia pada sindrom metabolik

3. Pasien dengan obesitas

4. Pasien dengan data Low Density Lipoprotein (LDL) dan trigliserida

5. Mengkonsumsi obat antilipid

6. Pasien yang bersedia menjadi responden 


\section{Alat dan Bahan}

Kuesioner ARMS (Adherence of Reffil Medication Scale), Catatan Rekam Medis pasien.

\section{Alur Penelitian}

Langkah pertama dilakukan pencarian data-data pasien seperti nama pasien, umur, jenis kelamin, alamat, nomor hp, tingkat pendidikan agar memudahkan saat akan melakukan pengisian kuesioner dan pengukuran lingkar perut. Selanjutnya peneliti akan menjelaskan tujuan dan maksud penelitian yang akan dilakukan guna mendapatkan persetujuan dari pasien. Langkah kedua setelah mendapatkan persetujuan dari pasien, pada awal penelitian dilakukan pengukuran lingkar perut dan pencatatan hasil laboratorium untuk LDL dan trigliserida. Langkah ketiga setelah jangka waktu yang telah ditentukan dilakukan pengukuran lingkar perut kembali dan diberikan kuesioner ARMS.

Tahap pengumpulan data dilakukan dengan mengevaluasi apakah data yang dibutuhkan untuk keperluan analisis data telah mencukupi. Jika data belum mencukupi, maka peneliti melakukan penelitian tambahan untuk melengkapi data tersebut. Jika sudah mencukupi, maka peneliti melakukan tahap selanjutnya.

Data penelitian berupa kuesioner partisipan kemudian data diinterpretasikan sesuai dengan pengambilan keputusan. Hasil interpretasi data analisis, selanjutnya di tuliskan dalam hasil analisis disertai dengan pembahasan, yaitu membandingkan hasil penelitian dengan teori-teori yang sesuai.

Populasi dan Sampel yang diambil yaitu pasien dislipidemia dengan sindrom metabolik di Rumah Sakit di Semarang. Teknik pengambilan sampel pasien sindrom metabolik dilakukan dengan menggunakan Teknik Non-Probability Sample yaitu dimana semua pasien tidak memiliki kesempatan yang sama. Pengambilan jumlah sampel dilakukan dengan perhitungan besar sampel dengan rumus Lemeshow:

Data yang sudah terkumpul selanjutnya dianalisis menggunakan analisis statistic deskriptif, yaitu analisis untuk menggambarkan faktor karakteristik. responden. Hubungan antara variabel bebas dan variable terikat pada penelitian ini digunakan uji statistik menggunakan Chisquare. Hasil penelitian ini dinyatakan bermakna jika $(\mathrm{p}<0,05)$ dan dinyatakan tidak bermakna jika $(p>0,05)($ Dahlan, 2014)

\section{HASIL DAN PEMBAHASAN}

Penelitian dilakukan pada bulan Agustus - Desember 2020 di Rumah Sakit di Semarang (Tabel 1). Penelitian ini bertujuan untuk mengetahui kepatuhan penggunaan obat pada pasien sindrom metabolik.

Berdasarkan hasil penelitian pasien sindrom metabolik, didapatkan data sebagai berikut, dimana pada penelitian mayoritas pasien sindrom metabolik merupakan pasien wanita $65(67,7 \%)$ sedangkan pasien laki-laki hanya berjumlah 31 pasien $(32,3 \%)$. Hal ini sama dengan penelitian (Bantas, et al., 2012) pada wanita prevalensi terjadinya sindrom metabolik lebih tinggi yaitu $21,3 \%$ dan pada laki-laki sebesar 12,9\%, perubahan siklus menopause pada wanita dikaitkan dengan peningkatan komponen sindrom metabolik, seperti obesitas, hipertensi, perubahan dari profil lipid, dan hiperinsulinemia (Akrom, et al., 2017). Peningkatan insiden SM selama periode postmenopause, risiko SM meningkat sebanyak 60\%. Akumulasi lemak pada ekstremitas bagian bawah pada wanita premenopause diduga disebabkan dari sekresi estrogen. Karena pada masa menopause terjadi perubahan pola sekresi horom yang menyebabkan lemak pada jaringan viseral

$$
\mathrm{n}=\frac{Z \alpha^{2} \times P \times Q}{L^{2}}
$$


Tabel 1. Data Demografi Pasien

\begin{tabular}{lcc}
\hline Karakteristik Demografi & Jumlah & \% \\
\hline Jenis kelamin & & \\
\hline Laki - laki & 31 & 32,3 \\
Perempuan & 65 & 67,7 \\
\hline Pendidikan & & \\
\hline Tidak Sekolah & 7 & 7,3 \\
SD & 34 & 35,4 \\
SMP & 12 & 12,5 \\
SMA & 33 & 34,4 \\
S1 & 6 & 6,3 \\
S2 & 2 & 2,1 \\
S3 & 2 & 2,1 \\
\hline Umur & & \\
\hline & & \\
\hline 31-40 & 8 & 8,3 \\
$41-50$ & 27 & 28,1 \\
51-60 & 38 & 39,6 \\
$61-70$ & 23 & 24 \\
\hline Penghasilan & & \\
\hline$<1$ juta & 52 & 54,2 \\
1-5 juta & 40 & 41,7 \\
5 juta & 4 & 4,1 \\
\hline Jaminan Kesehatan & & \\
\hline Umum & 13 & 13,5 \\
JKN NON PBI & 64 & 66,7 \\
JKN PBI & 19 & 19,8 \\
\hline Total & 96 & 100 \\
\hline & &
\end{tabular}

abdomen berakumulasi sehingga terjadi obesitas abdominal (Bantas, et al., 2012)

Dari data karakteristik yang didapat bahwa subjek penelitian dengan usia 51-60 tahun lebih berisiko mempunyai sindrom metabolik. Pasien dengan rentang usia 51-60 tahun sebanyak 38 pasien atau $39,6 \%$. Pada penelitian (Bantas, et al., 2012) wanita dengan usia >50 tahun terjadi peningkatan risiko SM (risiko SM meningkat 2,17 kali pada usia 50-59 tahun dan 3,58 kali pada usia 60 tahun dibanding dengan usia $<30$ tahun). Sedangkan pada pria di kelompok usia yang sama terjadi peningkatn namun tidak signifikan (peningkatan risiko SM 1,56 kali pada umur 50-59 tahun dan 2,26 kali pada umur 60 dibanding kelompok usia $<30$ tahun).

Tujuan dilakukannya pengobatan untuk mencegah komplikasi dan meningkatkan keberhasilan terapi. Keberhasilan terapi tidak hanya meliputi tentang ketepatan dosis, ketepatan pemilihan obat, tetapi juga kepatuhan dalam pengobatan (Akrom, et al.,
2017). Dalam penelitian ini alat yang digunakan untuk mengukur kepatuhan pasien terhadap penggunaan obat adalah menggunakan kuisioner ARMS (Adherence of Reffil Medication Scale), yaitu dengan menghitung skor dari masing-masing pasien sehingga dapat kita nilai bagaimana kepatuhan pasien dalam menggunakan obat. Untuk mengetahui kepatuhan pasien dalam kuesioner ini terdapat 12 pertanyaan, setiap pertanyaan dinilai dengan menggunakan skala Likert dari 1 hingga 4 setiap jawaban "tidak pernah", "kadang-kadang", "sering", dan "selalu" (Yunita, et al., 2019). Sehingga dengan menjawab 12 pertanyaan tersebut. Apabila pasien mendapat skor 12 maka pasien memiliki kepatuhan penggunaan obat tinggi (Tabel 2). Dalam kuisioner ini pasien dikatakan memiliki kepatuhan tinggi jika memiliki skor 12-16, memiliki kepatuhan sedang jika skor yang didapat 17-32, dan memiliki kepatuhan rendah jika skor yang didapatkan 33-48 (Yunita, et al., 2019)

Dari hasil uji chi-square kepatuhan

Tabel 2. Kepatuhan Penggunaan Obat terhadap Nilai Lingkar Perut pada Pasien Sindrom Metabolik

\begin{tabular}{ccccc}
\hline \multirow{2}{*}{ Kepatuhan } & \multicolumn{2}{c}{ Lingkar Perut } & \multirow{2}{*}{ Total } \\
\cline { 2 - 4 } & & Normal & Tidak Normal & \\
\hline \multirow{2}{*}{ Tinggi } & $\mathrm{N}$ & 2 & 39 & 41 \\
& $\%$ & $4,90 \%$ & $95,10 \%$ & $100 \%$ \\
\multirow{3}{*}{ Sedang } & $\mathrm{N}$ & 0 & 52 & 52 \\
& $\%$ & $0 \%$ & $100 \%$ & $100 \%$ \\
Rendah & $\mathrm{N}$ & 0 & 3 & 3 \\
& $\%$ & $0 \%$ & $100 \%$ & $100 \%$ \\
\hline
\end{tabular}

Keterangan : Nilai signifikansi $\mathrm{p}=0,254$

penggunaan obat pasien terhadap nilai lingkar perut didapatkan hasil bahwa sebanyak 41 pasien (100\%) memiliki kepatuhan yang tinggi, dengan 2 pasien $(4,90 \%)$ dalam kategori LP normal dan $39(95,10 \%)$ dalam kategori LP tidak normal. Pasien dengan kepatuhan sedang sebanyak 52 pasien $(100 \%)$ dalam kategori nilai LP tidak normal dan $0(0 \%)$ pasien dalam kategori nilai LP normal. Pasien dengan kepatuhan sedang sebanyak 3 pasien $(100 \%)$ dalam kategori nilai LP tidak normal dan $0(0 \%)$ pasien dalam kategori nilai LP normal. Didapat pula pada uji ini nilai sig. 
$0,254(\mathrm{p}>0.05)$ yang artinya tidak terdapat pengaruh kepatuhan penggunaan obat dengan nilai lingkar perut. Hal tersebut disebabkan karena untuk merubah LP tidak mudah dan membutuhkan waktu cukup lama tidak cukup hanya dengan 1 bulan saja tidak sama dengan kadar LDL dan trigliserid, tidak hanya dipengaruhi kurang patuhnya pasien dalam menggunakan obat tetapi juga perlunya pasien mengatur pola hidup dengan lebih baik. Karena dengan seseorang tidak menjaga pola hidup sehat dan menjaga pola makan benar orang tersebut memiliki risiko besar untuk terkena obesitas sentral (LP wanita $>80 \mathrm{~cm}$, pria $>90 \mathrm{~cm}$ ), dimana obesitas sentral akan menimbulkan risiko seperti diabetes dan hipertensi pada penderitanya (Triwinarto, et al., 2012). Lingkar perut merupakan salah satu indikator yang digunakan untuk menentukan obesitas pada seseorang (Sofa, 2018). Dimana obesitas merupakan salah satu ciri utama yang banyak dilaporkan penyebab terjadinya sindrom metabolik (Winarsi, et al., 2011). Akibat dari penurunan estrogen yaitu dengan meningkatnya obesitas abdomina merupakan alasan meningkatnya kejadian sindrom metabolik pada periode tertentu (Bantas, et al., 2012).

Tabel 3. Kepatuhan Penggunaan Obat terhadap Kadar LDL pada Pasien Sindrom Metabolik

\begin{tabular}{ccccc}
\hline \multirow{2}{*}{ Kepatuhan } & & \multicolumn{2}{c}{ LDL } & \multicolumn{2}{c}{ Total } \\
\cline { 2 - 4 } & & Normal & Tinggi & \\
\hline \multirow{2}{*}{ Tinggi } & $\mathrm{N}$ & 44 & 0 & 44 \\
& $\%$ & $100 \%$ & $0 \%$ & $100 \%$ \\
Sedang & $\mathrm{N}$ & 43 & 6 & 49 \\
& $\%$ & $87,80 \%$ & $12,20 \%$ & $100 \%$ \\
\multirow{4}{*}{ Rendah } & $\mathrm{N}$ & 3 & 0 & 3 \\
& $\%$ & $100 \%$ & $0 \%$ & $100 \%$ \\
\hline
\end{tabular}

Keterangan : Nilai signifikansi $\mathrm{p}=0,046$

Dari hasil uji chi-square (Tabel 3) kepatuhan penggunaan obat pasien terhadap kadar LDL didapatkan hasil bahwa sebanyak 44 pasien $(100 \%)$ memiliki kepatuhan yang tinggi, dengan 44 pasien $(100 \%)$ dalam kategori LDL normal dan $0(0 \%)$ pasien dalam kategori LDL tinggi. Pasien dengan kepatuhan sedang sebanyak 49 pasien (100\%) memiliki kepatuhan yang sedang, dengan 43 pasien $(87,80 \%)$ dalam kategori LDL normal dan 6
$(12,20 \%)$ pasien dalam kategori LDL tinggi. Pasien dengan kepatuhan rendah sebanyak 3 pasien $(100 \%)$ dalam kategori kadadr LDL normal dan $0(0 \%)$ pasien dalam kategori kadar LDL tinggi. Didapat pula pada uji ini nilai sig. $0,046(p<0.05)$ yang artinya terdapat pengaruh kepatuhan penggunaan obat dengan kadar LDL. Kadar LDL dalam tubuh perlu dilakukan pengawasan, karena apabila tidak dilakukan pengawasan sehingga tidak diketahui jika kadar LDL sedang dalam keadaan tinggi, maka akan menempel dan menimbulkan plak pada dinding pembuluh darah. Semakin lama plak akan menebal yang nantinya akan dapat merobek dinding arteri dan terjadi bekuan darah atau trombus sehingga aliran darah menjadi tersumbat.

Semakin lama trombus tersebut dapat menyumbat pembuluh darah koroner secara total sehingga pasokan oksigen ke otot jantug terhenti dan terjadilah infark miokard (Winarsi, et al., 2011).

Dari hasil uji chi-square kepatuhan

Tabel 4. Kepatuhan Penggunaan Obat terhadap Kadar Trigliserida pada Pasien Sindrom Metabolik

\begin{tabular}{ccccc}
\hline \multirow{2}{*}{ Kepatuhan } & \multicolumn{2}{c}{ Trigliserida } & \multirow{2}{*}{ Total } \\
\cline { 3 - 4 } & & Normal & Tinggi & \\
\hline \multirow{2}{*}{ Tinggi } & $\mathrm{N}$ & 37 & 4 & 41 \\
& $\%$ & $90,20 \%$ & $9,80 \%$ & $100 \%$ \\
\multirow{3}{*}{ Sedang } & $\mathrm{N}$ & 29 & 23 & 52 \\
& $\%$ & $55,80 \%$ & $44,20 \%$ & $100 \%$ \\
\multirow{3}{*}{ Rendah } & $\mathrm{N}$ & 1 & 2 & 3 \\
& $\%$ & $33,30 \%$ & $66,70 \%$ & $100 \%$ \\
\hline
\end{tabular}

Keterangan : Nilai signifikansi $\mathrm{p}=0,001$

penggunaan obat pasien terhadap kadar trigliserida (Tabel 4) didapatkan hasil bahwa sebanyak 41 pasien (100\%) memiliki kepatuhan yang tinggi, dengan 37 pasien $(90,20 \%)$ dalam kategori trigliserida normal dan $4(9,80 \%)$ pasien dalam kategori trigliserida tinggi. Pasien dengan kepatuhan sedang sebanyak 52 pasien $(100 \%)$, dengan 29 pasien $(55,80 \%)$ dalam kategori trigliserida normal dan $23(44,20 \%)$ pasien dalam kategori trigliserida tinggi.

Pasien dengan kepatuhan rendah sebanyak 3 pasien $(100 \%)$ dengan 1 pasien $(33,30 \%)$ dalam kategori trigliserida normal 
dan $2(66,70 \%)$ pasien dalam kategori trigliserida tinggi Didapat pula pada uji ini nilai sig. $0,001(p<0.05)$ yang artinya terdapat pengaruh kepatuhan penggunaan obat dengan kadar trigliserida. Dengan hasil tersebut terjadi penurunan yang sangat signifikan dari rerata tligliserid sebelum dan trigliserid sesudah, dan sedikit sesuai dengan kepatuhan penggunaan obat pasien yang sedang, karena mengingat untuk hasil trigliserid yang baik tidak hanya dipengaruhi pada kepatuhan penggunaan obat yang tinggi dan baik tetapi juga dengan mengelola pola makan dan pola hidup serta aktivitas fisik yang memiliki pengaruh penting (Watuseke, et al., 2016). Tinggi rendahnya tirgliserid berkaitan dengan adanya obesitas pada seseorang, pada individu yang mengalami obesitas kadar trigliseridanya lebih tinggi dibandingkan individu yang tidak obesitas (Putri \& Isti A, 2015). Berdasarkan (Chen, 2006) akumulasi trigliserid pada jaringan adiposa yang menyebabkan hipertrigliseridemia pada kondisi orang yang gemuk, kondisi ini juga ditemukan pada seseorang penderita sindrom metabolik.

Kepatuhan pasien sindrom metabolik terhadap terapi obat yang diberikan dengan perilaku pasien dalam menggunakan obat yang diberikan menjadi kunci terkontrolnya lemak tubuh, hipertensi, serta gula darah (Akrom, et al., 2017). Sedangkan pasien sendiri hanya berperan untuk patuh dalam minum obat, minum obat sesuai dengan dosis yang telah dianjurkan, serta mau ikut dalam memonitor efek apa yang dirasakan selama pengobatan, serta aktif dalam berbagi pengalaman setiap berobat (Keban, et al., 2013). Namun dengan beberapa faktor yang terjadi pada penelitian ini juga mempengaruhi kepatuhan pada pasien saat menjalani terapi pengobatan, seperti tingkat pendidikan yang bervariasi yang menyebabkan kesadaran pasien dalam menjalani terapi berbeda-beda, lalu penghasilan pasien yang berbeda-beda dan pasien dengan penghasilan rendah saat mempengaruhi terapi pengobatan dalam menebus atau membeli obat, apalagi pasien yang memperoleh obat dalam jumlah banyak yang membuat beberapa pasien malas untuk meminum semua obat sehingga ada beberapa obat yang dilewatkan untuk diminum.

Keterbatasan yang pada penelitian ini terdapat pada kurangnya evaluasi penggunaan obat yang dilakukan kepada pasien. Evaluasi terhadap kepatuhan pasien tidak dilakukan secara intensive karena hanya dilakukan satu kali evaluasi saja selama penelitian. Selain itu, sumber untuk mendapatkan informasi mengenai kriteria eksklusi hanya didapatkan dari sumber data saja tidak berdasarkan diagnosa yang pasti. Selain itu ada pula keterbatasan pada saat pengukuran lingkar perut karena tidak dilakukan hanya satu orang saja melainkan banyak orang dan berganti.

\section{KESIMPULAN (CONCLUSIONS)}

Adanya pengaruh kepatuhan penggunaan obat terhadap profil lipid dan tidak ada pengaruhnya pada lingkar perut pada pasien sindrom metabolik (SM) di Rumah Sakit di Semarang

\section{UCAPAN TERIMA KASIH}

Ucapan Terimakasih penulis bagi LPPM Universitas Islam Sultan Agung Semarang (Unissula) yang telah mendanai kegiatan ini melalui skema Program Penelitian Internal Tahun 2019/2020.

\section{Daftar Pustaka}

Agusti, N. I., 2014. Profil Rasio Kolesterol LDL dan HDL Pada Pasien Stroke Di Bagian Saraf RSUD Arifin Achmad Provinsi Riau Periode Januari Sampai Desember 2012. JOM FK No 2, Volume 1, p. 12.

Akrom, Darmawan, E. \& Maulida, N., 2017. Faktor-Faktor Berhubungan dengan Kejadian Hiperkreatininemia pada Pasien Berisiko Sindrom Metabolik di Puskesmas Jetis I. Pharmaciana, Volume 7(2), pp. 4-5. 
Bantas, K., Yosef, H. K. \& Moelyono, B., 2012. Perbedaan Gender pada Kejadian Sindrom Metabolik pada Penduduk Perkotaan di Indonesia. Jurnal Kesehatan Masyarakat Nasional, Volume 7(5), pp. 3-8.

Chen, H. C., 2006. Enhancing Energy and Glucose Metabolism by Disrupting Triglyceride Synthesis: Lessons from Mice Lacking DGAT1. J Nut and Met, pp. 3-10.

Dahlan, M. S., 2014. STATISTIK Untuk Kedokteran Dan Kesehatan. 6 ed. Jakarta: Epidemiologi Indonesia.

Hussar, D. A., 2006. Patient Compliance in Remington: The Science and Practice of Pharmacy. 21st edition ed. Maryland: Editor Genaro, A.Keban, S. A., Purnomo, L. B. \& Mustofa, 2013. Evaluasi Hasil Edukasi Farmasis Pada Pasien Diabetes Melitus Tipe 2 Di Rumah Sakit Dr. Sardjito Yogyakarta. Jurnal Ilmu Kefarmasian Indonesia, Volume 11(1).

Kripalani, S. et al., 2018. Validation of the Short Form of the Adherence to Refills and Medications Scale in Iranian Elders with Chronic Disease. Journal of Clinical and Diagnostic Research, Volume XII.

Kripalani, S., Risser, J., Gatti, M. E. \& Jacobson, T. A., 2009. Development and Evaluation of the Adherence to Refills and Medication Scale (ARMS) among Low-Literacy Patients with Chronic Disease. International Society for Pharmacoeconomics and Outcomes Research (ISPOR), Volume 12(I), pp. 118-123.

Magdalena, Mahpolah \& Yusuf, A., 2014. Faktor-Faktor Yang Berhubungan Dengan Sindrom Metabolik Pada Penderita Rawat Jalan Di RSUD Ulin Banjarmasin. Jurnal Skala Kesehatan, Volume V No. 2, pp. 1-3.

Mufarokhah, H., Putra, S. T. \& Dewi, Y. S., 2016. Self Management Program Meningkatkan Koping, Niat dan Kepatuhan Berobat Pasien PJK. Journal Ners No 1, Volume XI.

PERKENI, 2019. Pedoman Pengelolaan Dislipidemia Di Indonesia 2019. Jakarta: PB PERKENI.

Putri, S. R. \& Isti A, D., 2015. Obesitas sebagai Faktor Resiko Peningkatan Kadar Trigliserida. Majority No 9, Volume IV, p. 2.

Rini, S., 2015. Sindrom Metabolik. J Majority No 4, Volume IV, pp. 1-2.

Sofa, I. M., 2018. Kejadian Obesitas, Obesitas Sentral, dan Kelebihan Lemak Viseral pada Lansia Wanita. p. 229.

Triwinarto, A., Muljati, S. \& Jahari, A. B., 2012. Cut-Off Point Indeks Massa Tubuh (IMT) dan Lingkar Perut Sebagai Indikator Risiko Diabetes dan Hipertensi Pada Orang Dewasa Di Indonesia. Penel Gizi Makan No. 35, Volume II, p. 120.

Watuseke, A. E., Polii, H. \& Wowor, P. M., 2016. Gambaran kadar lipid trigliserida pada pasien usia produktif di Puskesmas Bahu Kecamatan Malalayang Kota Manado periode November 2014 - Desember 2014. Jurnal e-Biomedik (eBm) Volume IV, p. 4.

Winarsi, H., Wijayanti, S. P. \& Purwanto, A., 2011. Profil Lipid, Peroksidasi Lipid, dan Status Inflamatif Wanita. Jurnal Kesehatan Masyarakat Nasional, Volume 5(5), pp. 2-6.

Yunita, N., Andanalusia, M. \& Athiyah, U., 2019. Medication adherence in diabetes mellitus patients at Tanjung Karang Primary Health Care Center, Mataram. Journal of Basic and Clinical Physiology and Pharmacology 